\title{
Does Discipline and Work Coordination Can Improve Employee Performance Through Leadership Style as Intervening Variables? (Evidence from Public Companies in Indonesia)
}

\author{
Muhammad Ramaditya \\ \{ramaditya@stei.ac.id\} \\ Sekolah Tinggi Ilmu Ekonomi Jakarta, Indonesia
}

\begin{abstract}
This study aims to analyze the effect of work coordination and work discipline influence on employee performance through leadership style as intervening variables in PT. National Capital Madani as one of public companies in Indonesia. The research design is used an explanatory and association research. The study population was all employees of PT Permodalan Nasional Madani in Jakarta, while the sample technique used in this study was simple random sampling on 120 respondents. The method used is quantitative research and the analysis technique is used is structural equation modeling analysis (SEM). The results of this study indicate that work coordination and leadership have a significant effect on employee performance. Besides, work discipline does not have a significant effect on employee performance. Moreover, work coordination and discipline have a significant influence on the leadership style. This study gives implications to provide a knowledge and optimization of human resource management strategies. The choice of leadership style that can be well received by his subordinates and other continuous efforts are made to improve both operational improvement and continuous improvement to create a highly dedicated human resources management for the company's sustainability in the future.
\end{abstract}

Keywords: Work Coordination, Work Discipline, Employee Performance, Leadership

\section{Introduction}

PT Permodalan Nasional Madani (Persero) or PNM as one of public company in Indonesia which have objectives to accelerate poverty alleviation, actively moves to provide financing and empowerment to the Micro, Small and Medium Enterprises (SME's). One of the programs of PNM is the Mekaar program for fostering a prosperous family Economy). Prosperity in Indonesia cannot be avoided, but must be faced. Mekaar is for underprivileged women. One way to face pre-prosperity in Indonesia comes through PNM in 2015 through Mekaar. Mekaar provides services for underprivileged women who do not have the capital to open a business or capital to develop their businesses.

The Mekaar Program is a real form of government alignments through SOEs and improving the economy of small communities. PNM's flagship program can also be an effective effort to increase financial inclusion. Mekaar is an empowerment service through group-based financing for underprivileged women through mentoring and coaching by PNO Account Officers in the form of a business culture that is full of honesty, hard work discipline, 
harmony, kinship and mutual cooperation. Since starting at the end of November 2015, PNM Mekaar has successfully absorbed tens of thousands of employees and millions of customers. The credit platform is given starting from 500 thousand rupiah up to 3 million rupiah for each customer.

As of April 2018, Mekaar's customers nationwide have reached 2.8 million customers with more than 22 thousand employees accompanying them. Especially in West Java alone, there are at least 662 thousand pre-prosperous women who have become Mekaar's customers. By the end of 2018 the number of Mekaar customers had reached 4 million. The total funds disbursed have reached 6.67 trillion rupiah, with an average financing of 2.1 million per customer. Mekaar's Non-Performance Loan (NPL) is $0.25 \%$, this shows that the coaching system carried out to customers has succeeded in creating high loan repayments for each customer.

The problem that is currently still a challenge is the decrease in work motivation of some employees in achieving their work performance, lack of timeliness in completing the work provided, so that employees is reluctant or does not obey the regulations in force in the company. The influence that comes from the environment, such as coworkers who also lose enthusiasm and there are no examples that should be used as a reference in achieving good work performance, and the weak level of work coordination between one and another employee. Thus, the rhythm of work performance decreases and indirectly will certainly have an impact on the achievement of collective performance. If this is not immediately carried out properly, it will have an impact on the motivation of the mentoring customers.

Based on the results of the pre-survey and observed found that there are still some employees who are more concerned with personal interests than the interests of the company in completing work targets, where some employees will stop or leave their work if there is an urgent personal interest. Some employees also appear to be less than optimal in improving their performance, those who have finished their work prefer to be quiet and relaxed while waiting for breaks or hours after work. In addition, the lack of level of work coordination between one employee and other employees is also a problem that must be immediately resolved and analyzed the solution so that employee performance can improve simultaneously.

Many things which must be improved and many things must be fixed. PT Permodalan Nasional Madani can develop in the direction of which desirable because of participation active all levels of employees. Whole the employee layer must have a perception and the same understanding of how help a company or organization to grow and progress. The leader is in charge of giving the direction of his team's performance in order to achieve work goals that have been set by stakeholder. Leaders must build supportive synergies between its employees, so that the whole team can do work effectively and productive. Employees need to have work with maximum and productive synergy, when all employees work inside harmonious working conditions, conducive and productive. Despite the ability the individual of each employee is high, if they work for companies where working conditions are not harmonious, conducive then the motivation and performance will surely low, so productivity also works will be low. But on the contrary, though employee competencies are not too much high, they work in a condition right then the performance will be maximal.

Employees are now the most valuable entities and assets for the progress of the company. Human resources are the most important asset for the company, because it makes other company resources work according to their functions [1]. Companies that have employees with certain competencies and are reliable in their respective fields can work together between one work unit will directly impact on the achievement of company goals. Companies that have competent and professional employees can be interpreted that the 
company has a competitive advantage. Employees who have good qualifications in their fields, it is necessary to maintain human resources, this is done so that employees are loyal to the company.

Employees who have high levels of performance indirectly also have high levels of job satisfaction as well. Conversely, employees who have decreased performance levels, indicating there is a work relationship that is not going well, conditions of work environment that are uncomfortable for employees, ineffective work coordination patterns, workloads that are too overloaded which results in high levels of employee work stress as well as the lack of leadership in providing work support for its employees. Coordination of work that is not good, in addition to slowing work rhythm also has an impact on organizational performance, both employee performance and company performance on a large scale. in other research results said that coordination has a significant effect on employee performance [2].

Work discipline is enforced so that each employee can work in accordance with their respective duties and main functions. Employees who have high work discipline will directly have an impact on improving employee performance. This is because employees work in accordance with the deadline given by the leadership. So, when the leader gives the next job, then the employee is ready and has time to complete the work given. Another their research results said that work discipline has a significant effect on employee performance [3][4].

The problem of improving performance is closely related to the problem of how to instill awareness of the importance of discipline in working to be able to achieve the goal of high employee performance. Besides, work discipline is a form of obedience to the rules, both written and unwritten that have been set [5]. Thus, high work discipline, it is expected that an employee will be able to complete their tasks and responsibilities effectively and efficiently and on time according to a predetermined time.

The importance of leadership is useful as a managerial aspect that is able to manage human resources in order to work well. The company's operations depend on how well and how large the business leaders manage, give direction, make decisions and coordinate employees to do work in accordance with the directions and procedures that have been set. It is important for a leader to determine the form of leadership style so that it is in line with the vision and mission of the company, its work and subordinates. The right style of leadership is of course expected to be able to control work behavior and harmonize so that each employee's performance can improve.

The best leadership style is that leaders can stimulate their employees to improve their performance. Conversely, leadership style that is too authoritarian, prefers to rule and does not like to receive opinions and input from employees, can indirectly affect the performance of the employees themselves. Leadership style has direct and indirect effects that can affect the level of performance of its employees. Leadership style has a significant influence on employee performance [6][7].

The level of coordination and work discipline of employees directly can also affect the leadership style that is practiced by company leaders. Hence, coordination has a significant influence on leadership style [8]. Besides, work discipline has a significant influence on leadership style [9][10]. Coordination and work discipline have an influence on the leadership style in causality. This can be interpreted that each variable influences each other influencing each other. the leader is someone who inspires, persuades, influences and motivates the work of others. based on the description above, the researcher is interested in conducting research about the effect of work coordination and work discipline on employee performance through leadership style as intervening variables in PT Permodalan Nasional Madani. 


\section{Literature Review}

Work coordination is defined as an activity of directing, integrating and coordinating the elements of management and the work of subordinates in achieving company goals [11]. Work coordination also defines as the process of integrating goals and activities in separate units (units or functional areas) in an organization to achieve goals efficiently and effectively [12].

Work discipline as one's awareness and willingness to obey all company regulations and applicable social norms [11]. Work discipline also sees as a tool used by managers to change behavior and an effort to increase awareness and willingness to obey all applicable regulations in the company and social norms that apply [13]. There are 2 kinds of work disciplines according to is preventive discipline and corrective discipline [14].

Leadership as any ethical action carried out by individuals or groups to coordinate and give direction to individuals or groups who are members of a particular forum to achieve predetermined goals [15]. Leadership is a way that leaders use in interacting with their subordinates [16]. Leadership also defines as a pattern of behavior (words and actions) of a leader that is felt by others [17].

Employee performance is defining as the level of achievement of the implementation of a program of activities or policies in realizing the goals, objectives, vision and mission of the company as outlined through a company's strategic planning [18]. Employee performance is a formal and structured system used to measure, assess and influence traits related to work, behavior and work results, including the level of absence [13].

The performance comes from the word job performance or actual performance, namely employee performance (work performance) is the quality and quantity of work achieved by an employee in carrying out his duties in accordance with the responsibilities given to him [14]. Employee performance is a result achieved by employees in their work according to certain that apply to a job [19]. Employee performance is a result of work achieved by a person in carrying out the tasks assigned to him based on skill, experience, sincerity and time [11].

Coordination work is done to integrate all components in the company so that they can support each other from one part to another. The work coordination function will indirectly have an impact on improving employee performance. This is because each of the existing management units can work effectively and efficiently. Good work coordination can minimize the level of miscommunication between the management unit. Other study findings about work coordination have a significant effect on employee performance [20].

The enforcement of work discipline is carried out so that each employee can work optimally, in accordance with their respective functions and main tasks. Work discipline also serves to bind employees to be obedient and consciously comply with all the rules and norms that apply in the company. Employees who have high work discipline, directly have the ability to be able to complete tasks and functions in accordance with what is provided by the company. In other research results said that work discipline has a significant effect on employee performance [21].

Leaders who can directly or indirectly influence the performance of their employees. Leaders who can communicate work well to their employees, can directly affect the reception of messages by employees. Hence, employees can understand the responsibilities of their work. Employees who have high awareness will complete their responsibilities, will affect the achievement of their work. Hence, leadership has a significant influence on employee performance [8]. 
Good work coordination can integrate one part of the management unit with other management units. So that the work of each employee in each work unit can run according to the time given by the leadership. Good work coordination can help and facilitate leaders in coordinating between work units, employees, and work tasks that exist. Leaders can also be more controlling and resolve if there are problems at work with their subordinates. Moreover, work coordination has a significant influence on leadership style.

The high work discipline of the employees is causally highly influenced by good leadership style. This is because every employee will make the leader as an example in doing the job properly. High work discipline indicates that communication between leaders and employees is well formed. So that each element in the company can understand the duties and functions of each. Hence, work discipline has a significant influence on leadership style [9].

\section{Method}

This research is a type of explanatory research that explains the effect of causality between research variables through testing hypotheses on the same data. While at the level of explanation, the research used is associative research, namely research that aims to determine the effect between two or more variables. The sampling in this study is to take a simple random sampling technique, because sampling of members of the population is done randomly without regard to strata in the population of 120 respondents. The study population was all employees of PT Permodalan Nasional Madani in Jakarta by using questionnaire with the respondents. The data collection was gathered from January-April 2020 and the analysis tools technique is used is structural equation modeling analysis (SEM).

\section{Result and Discussion}

The descriptive data in this study consisted of the description of respondents, namely describing the data of respondents based on the classification of gender, age, education and length of work. While the description of the research variables explains the distribution of data on each of the research variables namely work coordination, work discipline, leadership style and employee performance variables. The classification of respondents in this study with male as many as 16 people. While respondents with a female gender were 104 people. Besides, the classification of respondents in this study based on age with an interval of 18 years to 25 years as many as 89 people. Respondents with an age interval of 26 years to 30 years were 10 people. While respondents with an age interval of more than 30 years were 21 people. Moreover, the classification of respondents based on education level of high school were 5 people. Respondents withhold diploma were 21 people. While respondents with a hold a degree were 94 people. Hence, the classification of respondents in this study based on length of work below 1 year as many as 16 people. Respondents with a range around 1 year to 2 years as many as 30 people. While the respondents with the classification of length of work more than 2 years were 74 people. 


\subsection{Structural Equation Modeling Analysis Test Results}

Testing the validity (variance validity) with CFA (Confirmatory Factor Analysis) is used to measure the level of ability of construct variables (indicators) in reflecting the latent variables of each of the research variables. Confirmatory factor analysis is used to test the theoretical concept indicators (manifest) that form latent variables, whether they are valid indicators as latent constructs. Following are the results of testing the variance validity with CFA as presented below on Table 1.

Table 1. Variance Validity Test Results with CFA

\begin{tabular}{|c|c|c|c|c|c|c|}
\hline \multicolumn{2}{|c|}{ Regression Weights } & Estimate & SE & $\mathrm{CR}$ & P. & Label \\
\hline $\mathrm{KD}$ & KD1 & 1 & & & & \\
\hline KD & KD2 & .778 & .101 & 7,693 & $* * *$ & par_6 \\
\hline KD & KD3 & 1,011 & .113 & 8.97 & $* * *$ & par 7 \\
\hline KD & KD4 & .973 & 0.112 & 8,659 & $* * *$ & par 8 \\
\hline KD & KD5 & 0.985 & .119 & 8,304 & $* * *$ & par 9 \\
\hline DK & DK1 & 1 & & & & \\
\hline $\mathrm{DK}$ & DK2 & 1,041 & 0.1 & 10,423 & $* * *$ & par_10 \\
\hline DK & DK3 & 0.922 & .107 & 8,615 & $* * *$ & par 11 \\
\hline $\mathrm{DK}$ & DK4 & 0.813 & .143 & 5.68 & $* * *$ & par 12 \\
\hline $\mathrm{DK}$ & DK5 & 0.841 & 0.098 & 8,565 & $* * *$ & par 13 \\
\hline DK & DK6 & 0.642 & 0.096 & 6,678 & $* * *$ & par 14 \\
\hline $\mathrm{NO}$ & GK1 & 1 & & & & \\
\hline $\mathrm{NO}$ & GK2 & 1,053 & .163 & 6.46 & $* * *$ & par 15 \\
\hline $\mathrm{NO}$ & GK3 & 1,108 & .169 & 6,567 & $* * *$ & par 16 \\
\hline $\mathrm{NO}$ & GK4 & 1.04 & .144 & 7,219 & $* * *$ & par 17 \\
\hline $\mathrm{NO}$ & GK5 & 0.965 & .137 & 7,021 & $* * *$ & par 18 \\
\hline $\mathrm{NO}$ & GK6 & 1,023 & .153 & 6,669 & $* * *$ & par_19 \\
\hline $\mathrm{NO}$ & GK7 & 1,105 & .164 & 6,726 & $* * *$ & par 20 \\
\hline $\mathrm{NO}$ & GK8 & 1,012 & .154 & 6,566 & $* * *$ & par 21 \\
\hline $\mathrm{NO}$ & GK9 & 1,027 & .149 & 6,897 & $* * *$ & par 22 \\
\hline $\mathrm{NO}$ & GK10 & .906 & 0.141 & 6,419 & $* * *$ & par 23 \\
\hline KK & KK1 & 1 & & & & \\
\hline KK & KK2 & 1.37 & .185 & 7,398 & $* * *$ & par_24 \\
\hline KK & KK3 & 1,241 & .165 & 7,538 & $* * *$ & par 25 \\
\hline KK & KK4 & .984 & .146 & 6,721 & $* * *$ & par_26 \\
\hline KK & KK5 & .974 & .148 & 6,574 & $* * *$ & par_27 \\
\hline KK & KK6 & 1,348 & .183 & 7.35 & $* * *$ & par 28 \\
\hline $\mathrm{KK}$ & KK7 & 1,143 & .159 & 7,198 & $* * *$ & par 29 \\
\hline KK & KK8 & .952 & .165 & 5,763 & $* * *$ & par 30 \\
\hline KD & KD6 & 0.54 & .109 & 4.95 & $* * *$ & par 32 \\
\hline
\end{tabular}

Source: Primary data processed by Ramaditya [1].

Based on Table 1. all indicators of construct variables from work coordination, work discipline, leadership style and employee performance variables have a significance probability value less than significance $\alpha$ of 0.05 with a $\mathrm{p}$ value of $* * *$, indicating that a significant probability value less than 0.001 and has a value convergent validity with a factor 
loading or standardized loading estimate more than significance $\alpha$ of 0.05 . This can be interpreted that all construct variables are able to reflect latent variables is consistent.

Moreover, another test is carried out to measure the level of variance in the convergent validity test. convergent validity has a high proportion of variance if the loading factor or standardized loading estimate value is 0.5 . Following are the results of convergency validity testing as presented on figure 1 . below can be explained that all construct variables have a loading factor or standardized loading estimate more than probability significance alpha of 0.5. This can be interpreted that each construct variable in this study has a high variance proportion in Figure 1.

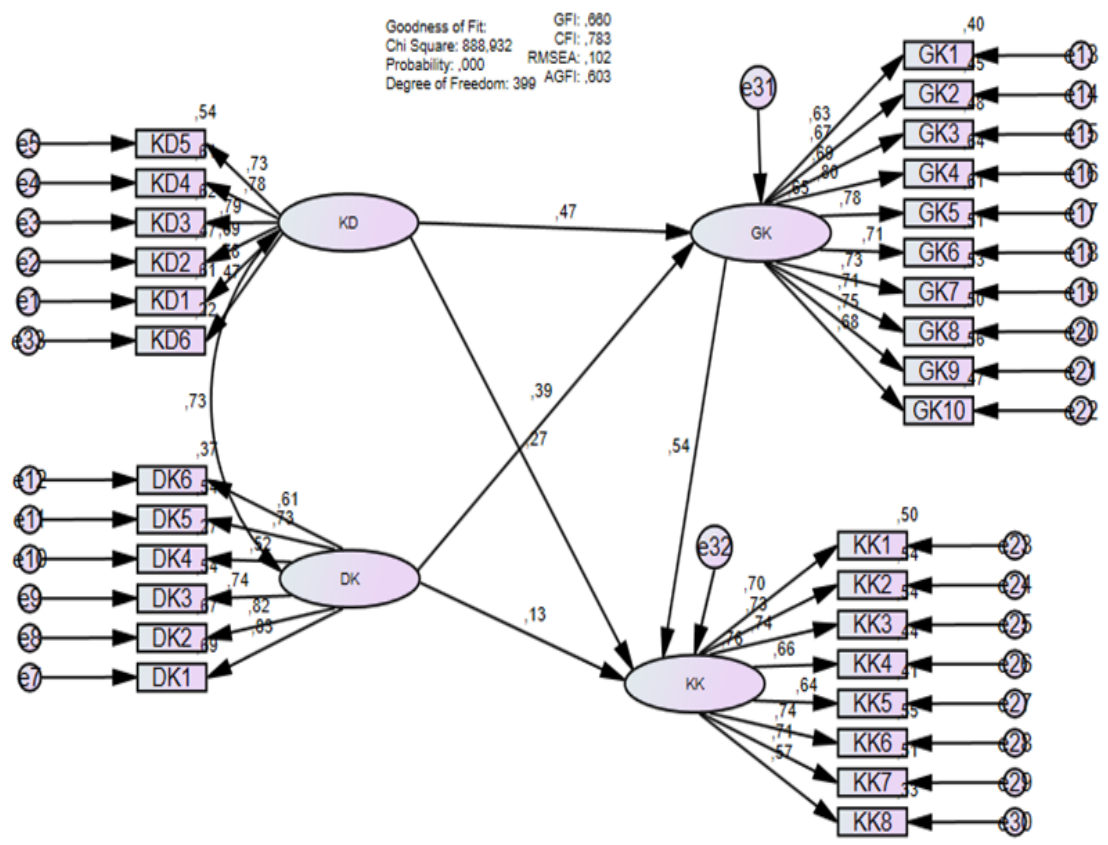

Figure 1. Decomposition Model by Ramaditya [1].

\subsection{Reliability Testing Results}

The construct reliability test is used to test the reliability and consistency of research data. It is said to meet the criteria for reliability testing well, if the value of construct reliability has a value of more than 0.7 . However, if the value of construct reliability is between a value of 0.6 to 0.7 , then it can still be accepted provided that the construct validity in the model is good. Following are the results of the standardized regression weights test as presented below.

Table 2. Standardized Regression Weights Testing Results

\begin{tabular}{|c|c|c|c|}
\hline \multicolumn{3}{|c|}{ Construction Variable } & Estimate \\
\hline NO & $<---$ & KD & .472 \\
\hline NO & $<---$ & DK & .394 \\
\hline KK & $<---$ & KD & 0.271 \\
\hline
\end{tabular}




\begin{tabular}{|c|c|c|c|}
\hline KK & $<---$ & DK & .134 \\
\hline KK & $<---$ & NO & 0.538 \\
\hline KD1 & $<---$ & KD & 0.782 \\
\hline KD2 & $<---$ & KD & .687 \\
\hline KD3 & $<---$ & KD & 0.789 \\
\hline KD4 & $<---$ & KD & 0.781 \\
\hline KD5 & $<---$ & KD & 0.734 \\
\hline DK1 & $<---$ & DK & 0.829 \\
\hline DK2 & $<---$ & DK & 0.818 \\
\hline DK3 & $<---$ & DK & 0.735 \\
\hline DK4 & $<---$ & DK & 0.516 \\
\hline DK5 & $<---$ & DK & 0.735 \\
\hline DK6 & $<---$ & DK & 0.606 \\
\hline GK1 & $<---$ & NO & 0.633 \\
\hline GK2 & $<---$ & NO & .672 \\
\hline GK3 & $<---$ & NO & .691 \\
\hline GK4 & $<---$ & NO & 0.798 \\
\hline GK5 & $<---$ & NO & .78 \\
\hline GK6 & $<---$ & NO & 0.715 \\
\hline GK7 & $<---$ & NO & 0.729 \\
\hline GK8 & $<---$ & NO & .705 \\
\hline GK9 & $<---$ & NO & 0.748 \\
\hline GK10 & $<---$ & NO & .684 \\
\hline KK1 & $<---$ & KK & .705 \\
\hline KK2 & $<---$ & KK & 0.733 \\
\hline KK3 & $<---$ & KK & 0.737 \\
\hline KK4 & $<---$ & KK & 0.662 \\
\hline KK5 & $<---$ & KK & 0.64 \\
\hline KK6 & $<---$ & KK & 0.739 \\
\hline KK7 & $<---$ & KK & 0.713 \\
\hline KK8 & $<---$ & KK & 0.571 \\
\hline KD6 & $<---$ & KD & \\
\hline Source: Primary data processed by Ramaditya 11. \\
\hline
\end{tabular}

Based on Table 2. calculation of the number of measurement errors in the construct variable, the value of the validity test results with the average variance extracted (construct reliability) as presented below.

Table 3. Construct Reliability Testing Results

\begin{tabular}{|l|c|c|}
\hline \multicolumn{1}{|c|}{ Latent Variable } & \multicolumn{3}{c|}{ Value of the Variance Ectracted } \\
\hline Coordination of work & $4,985 /(4,985+3,015)$ & .623 \\
\hline Work discipline & $4,767 /(4,767+3,233)$ & 0.596 \\
\hline Leadership style & $7,693 /(7,693+3,307)$ & 0.699 \\
\hline
\end{tabular}




\begin{tabular}{|l|l|l|}
\hline Employee performance & $5,500 /(5,500+2,500)$ & .688 \\
\hline
\end{tabular}

Source: Primary data processed by Ramaditya [1].

Based on Table 3. of the construct reliability test above, it can be explained that the variables in this study have construct reliability values close to 0.7 [22]. This can be interpreted that the mean values of the construct variables can reflect each latent variable very well. This means that the latent variables in this study are reliable and feasible to be used in the study.

\subsection{Validity Testing Results}

The heading for subsubsections should be in Times New Roman 11-point italic with initial letters capitalized.

Validity testing with Average Variance Extracted (AVE) is a confirmatory factor analysis test by looking at the average value of the variance between constructs (indicators) of each latent variable. It said the research data is valid with AVE testing, if the average value of AVE more than is 0.5 . Following are the results of standardized regression weights testing as presented below on Table 4.

Table 4. Number of Standard Loading Squares

\begin{tabular}{|c|c|c|c|c|c|c|}
\hline Latent Variable & \multicolumn{5}{|c|}{ Construct variable } & Total \\
\hline \multirow{2}{*}{ Coordination of work } & .223 & 0.073 & 0.612 & .472 & .623 & \multirow{2}{*}{3,371} \\
\hline & 0.610 & 0.539 & 0.220 & & & \\
\hline \multirow{2}{*}{ Work discipline } & .155 & 0.018 & .687 & .669 & 0.540 & \multirow{2}{*}{3,243} \\
\hline & 0.266 & 0.540 & .367 & & & \\
\hline \multirow{3}{*}{ Leadership style } & .401 & .452 & .477 & 0.637 & .608 & \multirow{3}{*}{5,431} \\
\hline & 0.511 & 0.531 & .497 & 0.560 & 0.468 & \\
\hline & .289 & & & & & \\
\hline \multirow{2}{*}{ Employee performance } & .497 & 0.537 & 0.543 & 0.438 & 0.410 & \multirow{2}{*}{3,806} \\
\hline & 0.546 & 0.508 & .326 & & & \\
\hline
\end{tabular}

Source: Primary data processed by Ramaditya [1].

Based on Table 4. the calculation of the number of standard loading squares above, we can get the value of the number of measurement errors which is obtained from the reduction of 1 with the value of each construct variable. Based on the calculation of the number of measurement errors of the construct variables above, we can get the value of the validity test results with the average variance extracted below.

Table 5. Results of Square Roots Average Variance Extracted Value

\begin{tabular}{|c|c|}
\hline Latent Variable & Average Variance Extracted Value Squared \\
\hline Coordination of work & 0.421 \\
\hline Work discipline & 0.405 \\
\hline Leadership style & .494 \\
\hline Employee performance & .476 \\
\hline \multicolumn{2}{|c|}{ Source: Primary data processed by Ramaditya [1]. }
\end{tabular}

Based on Table 5. the results of the average variance extracted validity squared on Table 5 , it can be explained that the variables in this study have average variance extracted values 
close to 0.5 . This can be interpreted that the average value of the construct variable can reflect the latent variable is good. Based on the correlation estimate values of the latent variables above, a correlation matrix can be obtained between the values of the latent variables and the value of the square root AVE as presented below.

Table 6. Correlation Between Latent Variables and Square Root AVE

\begin{tabular}{|c|c|c|c|c|}
\cline { 2 - 5 } \multicolumn{1}{c|}{} & KD & DK & NO & KK \\
\hline KD & $\mathbf{0 . 4 2 1}$ & 0,000 & .472 & 0.271 \\
\hline DK & 0,000 & $\mathbf{0 . 4 0 5}$ & .394 & .134 \\
\hline NO & .472 & .394 &. $\mathbf{4 9 4}$ & 0.538 \\
\hline KK & 0.271 & .134 & 0.538 & $\mathbf{. 4 7 6}$ \\
\hline
\end{tabular}

Source: Primary data processed by Ramaditya [1].

Based on the Table 6, it can be explained that the square root value AVE correlation value of latent variables. This can be interpreted that the data in this study with AVE square root testing is good validity. While for others AVE square root is not higher than the level of correlation between constructs. So, the conclusion remains consistent with the previous analysis. So that the data in this study is feasible to use in this study.

\subsection{Goodness of Fit}

Goodness of Fit testing is used to determine whether the modeling that is built meets the fit criteria or not. To find out this test we need some suitability index and cut-off value which is then to be used in testing a model. In consider whether or not modification is needed for a model, by looking at the amount of residual generated in the model. Several suitability indexes and their cut-off values are used in testing whether a model can be accepted or rejected as described below.

Table 7. Goodness of Fit Index Testing Results

\begin{tabular}{|c|l|c|c|c|}
\hline No & Goodness of Fit Index & Cut-off value & $\begin{array}{c}\text { Analysis } \\
\text { Results }\end{array}$ & $\begin{array}{c}\text { Model } \\
\text { Evaluation }\end{array}$ \\
\hline 1 & Chi-Square & $\begin{array}{c}\text { Value of the chi square } \\
\text { distribution, df 399, 5\% sig } \\
\text { level }=\leq 464.62\end{array}$ & 888,932 & Marginal \\
\hline 2 & Significance Probability & $\geq 0.05$ & 0.00 & Marginal \\
\hline 3 & GFI & $\geq 0.90$ & 0.66 & Marginal \\
\hline 4 & AGFI & $\geq 0.90$ & 0.60 & Marginal \\
\hline 5 & IFI & $\geq 0.90$ & 0.79 & Marginal \\
\hline 6 & TLI & $\geq 0.90$ & .76 & Marginal \\
\hline 7 & CFI & $\geq 0.90$ & .78 & Marginal \\
\hline 8 & NFI & $\leq 0.90$ & .67 & Marginal \\
\hline 9 & RMSEA & $\leq 2.00$ & .10 & Marginal \\
\hline 10 & CMIN/DF & 2.23 & Marginal \\
\hline
\end{tabular}

Source: Primary data processed by Ramaditya [1].

Based on Table 7. results of the goodness of fit test as presented above, it can be explained that the values of IFI, TLI and CFI are close to the cut-off value or close to 1 . This shows that the results of the analysis are getting closer to value 1, indicating the existence of a 
very good fit. Although the results of the study did not reach the recommended cut-off value, it approached the cut-off value. So that the conclusions that can be drawn in this testing model are that this research model is feasible to use in the study.

\subsection{Regression Weight}

After testing the structural equation with the goodness of fit method, the next step is to test the hypothesis. The hypothesis can be accepted $(\mathrm{Ha}=$ accepted $)$ if the criterion more than 2.80 at the $\alpha$ significance level of 0.01 or the critical ratio more than 1.96 for the $\alpha$ significance of 0.05 . This states that the independent variable and intervening variable has a significant effect on the dependent variable. The following are the results of the calculation of parameter estimates in the structural equation modeling analysis models that have been studied, as presented below.

Table 8. Regression Weights Testing Results

\begin{tabular}{|c|c|c|c|c|c|c|}
\hline \multicolumn{8}{|c|}{ Regression Weights } & Estimate & SE & CR & P. \\
\hline KD & $--->$ & NO & .381 & .108 & 3,527 & $* * *$ \\
\hline DK & $--->$ & NO & 0.332 & .107 & 3,105 & 0.002 \\
\hline KD & $--->$ & KK & .187 & 0.087 & 2,143 & 0.032 \\
\hline DK & $--->$ & KK & 0.097 & 0.088 & 1,105 & 0.269 \\
\hline NO & $--->$ & KK & 0.461 & 0.125 & 3,672 & $* * *$ \\
\hline \multicolumn{7}{|c|}{ Source: Primary data processed by Ramaditya [1]. }
\end{tabular}

Based on the Table 8 . test results of the estimated parameter (regression weight) as presented above, the statistical equation can be obtained as follows:

a) Work coordination variable has a critical ratio value of 3.527 more than 1.96 with a significance probability value less than significance $\alpha$ of 0.05 . His decision was to accept $\mathrm{Ho}$ and reject Ha. This can be interpreted that the work coordination variable has a significant influence on leadership style.

b) The work discipline variable has a critical ratio value of 3.105 more than 1.96 with a significance value of 0.002 less than significance of $\alpha$ of 0.05 . His decision was to accept Ho and reject Ha. This can be interpreted that work discipline variables have a significant influence on leadership style.

c) Work coordination variable has a critical ratio value of 2.143 more than 1.96 with a significance value of 0.032 less than significance $\alpha$ of 0.05 . His decision was to accept Ho and reject Ha. This can be interpreted that the work coordination variable has a significant influence on employee performance.

d) The work discipline variable has a critical ratio value of 1.105 more than 1.96 with a significance value of 0.269 less than significance of $\alpha$ of 0.05 . His decision was to accept Ho and reject Ha. This can be interpreted that the work discipline variable does not have a significant effect on employee performance.

e) The leadership style variable has a critical ratio value of 3.672 more than 1.96 with a probability value of significance less than $\alpha$ of 0.05 . His decision was to accept Ho and reject Ha. This can be interpreted that the leadership style variable has a significant influence on employee performance.

Following are the results of the direction of the effect of causality on each path as presented below. 


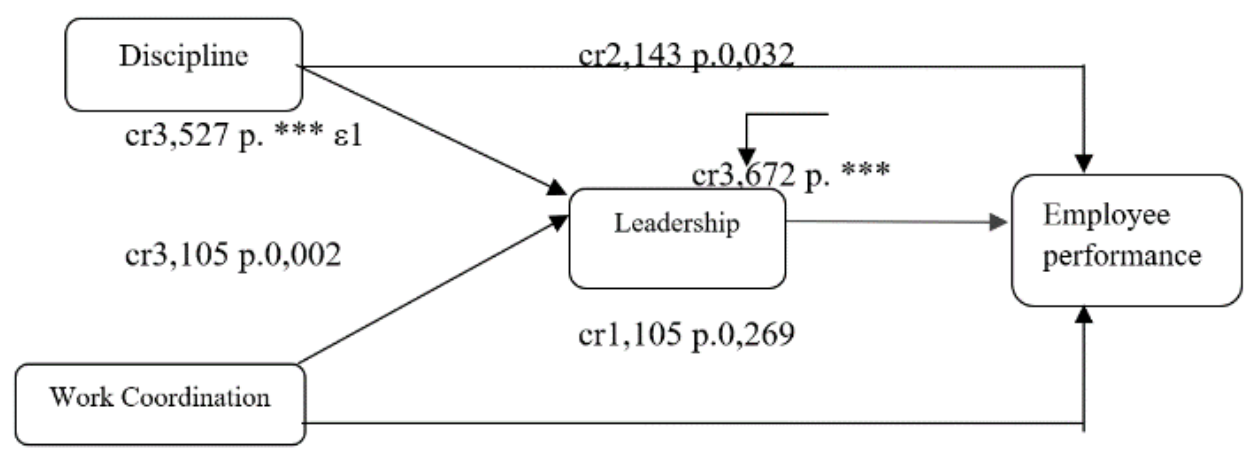

Fig. 2. Results of Significance in the Direction of Causal Influence Pathways Source: Primary data processed by Ramaditya [1].

Based on Figure 2. it can be explained that the work coordination variable directly has a significant effect on employee performance and indirectly has a significant effect on employee performance through leadership style. This indicates that the leadership style variable is a good intervening variable in explaining the variation of the effect of the work coordination variable on employee performance.

Table. 9. Direct, Indirect and Total Impact Test Results

\begin{tabular}{|l|c|c|c|}
\hline \multicolumn{1}{|c|}{ Variable } & $\begin{array}{c}\text { Influence } \\
\text { Direct }\end{array}$ & $\begin{array}{c}\text { Influence } \\
\text { Indirect }\end{array}$ & $\begin{array}{c}\text { Influence } \\
\text { Total }\end{array}$ \\
\hline Coordination of work & .187 & .175 & .363 \\
\hline Work discipline & 0.097 & .153 & .250 \\
\hline Leadership style & 0.461 & 0,000 & 0.461 \\
\hline \multicolumn{3}{|c}{$\begin{array}{c}\text { Dependent variable: Employee performance } \\
\text { Source: Primary data processed (2020). }\end{array}$}
\end{tabular}

Based on table 9. It can be explained that the work coordination variable has a direct effect of 0.187 and an indirect effect of 0.175 . The work discipline variable has a direct effect of 0.097 and an indirect effect of 0.153 . While the leadership style variable has a direct influence of 0.461 .

\subsection{Findings}

Based on the findings, the work coordination variable has a significant influence on employee performance. The results of this study are consistent with the results of research conducted by other study that found the work coordination variable had a significant effect on employee performance [2][20]. Other findings can be interpreted that the work discipline variable does not have a significant effect on employee performance. The results of this study are not in accordance with the results of research conducted who in their research said that work discipline variables had a significant effect on employee performance [3][5].

Moreover, the results of this study are consistent with the results that the leadership style variable had a significant influence on employee performance [6]. However, the results of this study are consistent with the results that work coordination variables have a significant effect on leadership style [8]. Furthermore, the results of this study are in accordance with the results 
of research findings that work discipline variables had a significant influence on leadership style [9][10].

\section{Conclusion}

Finally, the conclusions in this study are as work coordination has a significant effect on employee performance; work discipline does not have a significant effect on employee performance; leadership has a significant influence on employee performance; work coordination has a significant influence on leadership style; and work discipline has a significant influence on leadership style.

The results of this study are expected to provide useful recommendations for companies, especially for Personnel Managers or Human Resources of PT Permodalan Nasional Madani related to the optimization of human resource management policies. The choice of leadership style that can be well received by his subordinates. In addition, efforts to continuously make improvements both operational improvement and continuous improvement to produce superior management and high dedication to the company.

This study presents opportunities for further research. First, additional research is indicated as to whether other factor such as organizational agility and knowledge management may be a limiting factor in achieving employee performance. Second, the case subject was a public company in Indonesia. Future research should compare the results from surveying similarly sized public government from different regions in the world such as Malaysia and differently sized institutions. Finally, more research could be undertaken to compare the results of different organizational roles within public government company in Indonesia.

\section{References}

[1] M. Ramaditya and G. Nazzario, "Faktor Faktor Yang Memberikan Implikasi Terhadap Keterikatan Pekerja," J. Ris. Manaj. dan Bisnis Fak. Ekon. UNIAT, vol. 5, no. 2, pp. 61-72, 2020.

[2] D. F. Octorano, "Pengaruh Koordinasi, Kompetensi Dan Disiplin Terhadap Kinerja Pegawai Unit Layanan Pengadaan Kementerian Agama Pusat (Ulp Kemenag Pusat)," Mix J. Ilm. Manaj., vol. 5, no. 1, p. 157140, 2015.

[3] A. Isvandiari and B. Al Idris, "Pengaruh Kepemimpinan Dan Disiplin Kerja Terhadap Kinerja Karyawan Pada PT Central Capital Futures Cabang Malang," J. Ilm. Bisnis dan Ekon. Asia, vol. 12 , no. 1, pp. 17-22, 2018.

[4] E. A. Apalia, "Effects of discipline management on employee performance in an organization: The case of county education office human resource department, Turkana County," Int. Acad. J. Hum. Resour. Bus. Adm., vol. 2, no. 3, pp. 1-18, 2017.

[5] M. Mansur, "Pengaruh Disiplin Kerja terhadap Kinerja Karyawan Melalui Kualitas Kerja sebagai Variabel Intervening," Futur. J. Manaj. dan Akunt., vol. 5, no. 2, pp. 171-177, 2018.

[6] S. Suyatin, "The Effect of Leadership Style on Employee Performance of the PPIC Division of PT. Prima Components Indonesia BSD-Tangerang," PINISI Discret. Rev., vol. 3, no. 1, pp. 6168, 2019.

[7] A. Rivai, "Personnel Performance Analysis: Leadership, Work Discipline and Organizational Commitment (A study of KODAM Transportation Unit Personnel I/Bukit Barisan)."

[8] P. Bolton, M. K. Brunnermeier, and L. Veldkamp, "Leadership, coordination, and corporate culture," Rev. Econ. Stud., vol. 80, no. 2, pp. 512-537, 2013.

[9] S. Effendy and J. R. Putra, "Pengaruh Gaya Kepemimpinan, Lingkungan Kerja dan Budaya Organisasi Terhadap Disiplin Kerja Karyawan pada PT. Bank Sumut Cabang Sukaramai,” Sos. 
Polit. Ekon.

[10] S. Muttaqin, M. D. M. Mukzam, and Y. Mayowan, "Pengaruh Gaya Kepemimpinan Terhadap Disiplin Kerja (Studi pada Karyawan PT PLN (Persero) Area Pelayanan Malang)," J. Adm. Bisnis, vol. 41, no. 1, pp. 65-71, 2016.

[11] M. Hasibuan, Manajemen Sumber Daya Manusia. Jakarta: Bumi Aksara, 2014.

[12] T. H. Handoko, "Manajemen," 2013.

[13] M. Deddy and R. Veithzal, "Kepemimpinan dan Perilaku organisasi," Jakarta Raja Wali Pers, 2011.

[14] A. P. Mangkunegara, "Company Human Resource Management," Bandung PT Remaja Rosdakarya, 2012.

[15] M. Ramaditya, "Examining the Impact of Corporate Social Responsibility Towards Employee Engagement (A case study: Telekom Malaysia Berhad in Kedah)," in 5th Annual International Conference on Management Research (AICMaR 2018), 2019, pp. 126-133.

[16] F. Tjiptono, Strategi Pemasaran: Edisi kedua. Yogyakarta, 2010.

[17] H. Hadiwijaya, "Pengaruh gaya kepemimpinan dan motivasi terhadap kinerja karyawan pada unit usaha pengembangan dan lingkungan pt. Perkebunan mitra ogan baturaja," 2013.

[18] M. Abdullah, "Management and Employee performance evaluation," Aswaja Press. Jakarta, 2014.

[19] S. P. Robbins and T. A. Judge, Organizational behavior, global edition. Pearson Education UK, 2016.

[20] D. Fitriasari and B. Suzanto, "Pengaruh Motivasi Kerja, Disiplin Kerja dan Koordinasi terhadap Kinerja Pegawai (suatu Studi pada Cabang Pelayanan Dinas Pendapatan Daerah Provinsi Wilayah Kota Bandung III Soekarno Hatta)," J. Ekon. Bisnis Entrep., vol. 8, no. 2, p. 41351, 2014.

[21] M. Zafar, E. Karim, and O. Abbas, "Factors of Workplace Environment that Affects Employee Performance in an Organization: A study on Greenwich University of Karachi," 2017.

[22] I. Ghozali, "Model Persamaan Struktural Konsep Aplikasi dengan Program AMOS 21.0," Semarang Badan Penerbit Univ. Diponegoro, 2011. 